\title{
Epidemiological Analysis of Clones and Cultivars of Potato in Soil Naturally Infested with Ralstonia solanacearum Biovar 2
}

\author{
José R.P. Silveira1', Valmir Duarte 2 , Marcelo G. Moraes², Carlos A. Lopes ${ }^{3}$, José M. Fernandes 4 , \\ Valmor Barni ${ }^{5}$ \& João L.N. Maciel ${ }^{4}$
}

${ }^{1}$ Fundação Estadual de Pesquisa Agropecuária - FEPAGRO, Rua Gonçalves Dias 570, CEP 90130-060, Porto Alegre, RS, Brazil; ${ }^{2}$ Departamento de Fitossanidade, Universidade Federal do Rio Grande do Sul - UFRGS, Cx. Postal 15100, CEP 90001-970, Porto Alegre, RS, Brazil, e-mail: valmir@ufrgs.br; ${ }^{3}$ Embrapa Hortaliças, Cx. Postal 218, CEP 70359-970, Brasília, DF, Brazil; ${ }^{4}$ Embrapa Trigo, Cx. Postal 451, CEP 99001-970, Passo Fundo, RS, Brazil; ${ }^{5}$ Centro de Pesquisa de Agroindústria, FEPAGRO, Cx. Postal 172, CEP 95100-970, Caxias do Sul, RS, Brazil.

Author for correspondence: Valmir Duarte

SILVEIRA, J.R.P., DUARTE, V., MORAES, M.G., LOPES, C.A., FERNANDES, J.M., BARNI, V. \& MACIEL, J.L.N. Epidemiological analysis of clones and cultivars of potato in soil naturally infested with Ralstonia solanacearum biovar 2. Fitopatologia Brasileira 32:181-188. 2007.

\begin{abstract}
The objectives of this study were to evaluate the progress of Ralstonia solanacearum bacterial potato wilt biovar 2 (race 3) in 14 potato (Solanum tuberosum L.) cultivars or clones, the resistance of potato clone MB 03 (selected in Brasília, Brazil) to race 1 of $R$. solanacearum, and the occurrence of the pathogen in tubers harvested from asymptomatic potato plants. During the spring (September to the end of November in the southern hemisphere) of 1999 and 2000, 14 cultivars or clones were grown in a field naturally infested with $R$. solanacearum biovar 2, in Caxias do Sul, RS. The number of wilted potato plants was recorded each week and a disease progress curve plotted, the resistance of the potato genotypes to bacterial wilt being evaluated by determining the area under the curve. Various models were evaluated to fit the curves, with the logistic model being the best fit. At the end of each growing season tubers produced by asymptomatic plants were harvested and stored until budding and then tested for the presence of $R$. solanacearum. Cultivar Cruza 148 and clone MB 03 were the most resistant but both showed tubers with latent infections. The epidemiological implications of the incidence of $R$. solanacearum biovar 2 (race 3 ) in potato crops, as well as the resistance of certain genotypes that may harbor latent infections, are important aspects to be considered in the integrated management of bacterial wilt.
\end{abstract}

Additional keywords: bacterial wilt, disease progress, latent infection, logistic, monomolecular, Gompertz.

\section{RESUMO}

Análise epidemiológica de clones e cultivares de batata em solo naturalmente infestado com a biovar 2 de Ralstonia solanacearum

Os objetivos deste estudo foram avaliar o progresso da murcha bacteriana, a resistência do clone MB 03, selecionado para a raça 1 em Brasília, e detectar a presença do patógeno em tubérculos colhidos de plantas assintomáticas. Durante a primavera (setembro a final de novembro no hemisfério sul) de 1999 e 2000, 14 cultivares ou clones foram cultivados num campo naturalmente infestado com R. solanacearum biovar 2, em Caxias do Sul, RS. O número de plantas com sintomas de murcha foi registrado semanalmente para a obtenção da curva de progresso da doença. Para comparar a resistência dos genótipos de batata à murcha bacteriana foi calculada a área sob a curva de progresso da doença. Dentre os modelos avaliados para ajuste das curvas, o modelo logístico foi o que melhor se ajustou. Ao final das avaliações, em cada período de cultivo, os tubérculos produzidos por plantas assintomáticas foram coletados e armazenados até o início da brotação, quando foram submetidos a testes para detectar a presença de $R$. solanacearum. A cultivar Cruza 148 e o clone MB 03 foram os genótipos mais resistentes, mas ambos apresentaram tubérculos com infecções latentes. As implicações epidemiológicas da incidência de $R$. solanacearum raça 3 em lavouras de batata, bem como da resistência de determinados genótipos que podem propiciar tubérculos com infecções latentes, são aspectos de importância para o manejo integrado da murcha bacteriana no RS.

Palavras-chave adicionais: murcha bacteriana, progresso da doença, infecção latente, logístico, monomolecular, Gompertz.

\section{INTRODUCTION}

The phytopathogenic bacterium Ralstonia solanacearum (Smith) Yabuuchi et al. 1995 [sin.

Part of the Doctoral Thesis of the first author. Universidade Federal do Rio Grande do Sul. Porto Alegre RS. Brazil. 2002.
Pseudomonas solanacearum (Smith) Smith 1914] is a major pathogen which mainly affects Solanaceae species, although it can also infect plants belonging to more than 50 other families. This phytopathogen has been considered as the main constraint to growing potatoes (Solanum tuberosum L.) in tropical and subtropical regions and countries with warm climates (Hayward, 1995). The different $R$. solanacearum

Fitopatol. Bras. 32(3), maio - jun 2007 
strains are highly variable and have been classified into biovars in accordance with their ability to oxidize different carbon sources races (Hayward, 1991). Under normal conditions two $R$. solanacearum strains infect potato plants, biovar 1 (race 1), disseminated in Brazil, and biovar 2 (race 3 ) which attacks potato plants mainly in more temperate regions, with biovar 2 isolates from cooler regions being considered as belonging to race 3 . Race 1 strains can survive longer in soil, occur in warmer regions (26-36 $\left.{ }^{\circ} \mathrm{C}\right)$ and have a wider host range, while race 3 strains occur in cooler regions $\left(15-20^{\circ} \mathrm{C}\right)$, produce latent infections of potato tubers and present a narrower host range, of which potato is the most important (Hayward, 1991; Lopes, 1994).

The worldwide dissemination of $R$. solanacearum race 3 is associated with seed potato tubers, because latent $R$. solanacearum populations can colonize the vascular tissues of the tuber without inducing symptoms of disease (Hayward, 1991).

The major source of resistance to bacterial potato wilt caused by $R$. solanacearum comes from clones of Solanum phureja, a cultivated diploid species (French et al., 1998). The Brazilian National Vegetable Research Center (Centro Nacional de Pesquisas de Hortaliças (part of the Brazilian agricultural company Empresa Brasileira de Pesquisa Agropecuária - Embrapa), or Embrapa Hortaliças, in partnership with the International Potato Center (Centro Internacional de la Papa (CIP) http:// www.cipotato.org) has been selecting genotypes from potato clones obtained from true potato seeds produced by crossing several Solanum species harboring different resistance genes. The clones were selected for commercial characteristics and subsequently sown in an area naturally infested with $R$. solanacearum race 1, using the Achat and Cruza 148 cultivars as resistant cultivars and the Baronesa cultivar as the susceptible cultivar (Quezado-Soares et al. 1997; Lopes et al., 1998).

To obtain stable resistance pattern clones selected in a single site must be tested in sites where different strains of the pathogen occur (Reifschneider \& Lopes, 1997). Phytopathogenic $R$. solanacearum strains, principally race 3, are endemic in the southernmost Brazilian state of Rio Grande do Sul (Silveira et al., 2002), and the use of potato cultivar resistance against $R$. solanacearum races 1 and 3 is an important tool for the development of a strategy controlling bacterial potato wilt (QuezadoSoares et al., 1997).

The aim of the work described in this paper was to evaluate the progress $R$. solanacearum bacterial wilt in potato cultivars and clones grown in an area naturally infested with strains of $R$. solanacearum biovar 2 (race 3 ) and assess the resistance of potato clone MB-03, previously tested in Brasília for its resistance to $R$. solanacearum race 1 , to $R$. solanacearum biovar 2 (race 3 ). We also used the double antibody sandwich enzyme-linked immunosorbent assay (DAS-ELISA) and the polymerase chain reaction
(PCR) to detect $R$. solanacearum in tubers harvested from asymptomatic potato plants.

\section{MATERIAL AND METHODS}

\section{Place, date and experiment design}

The experimental area was located at an altitude of $760 \mathrm{~m}$ in the Northeast Mountain region (Serra do Nordeste) of the Fazenda Souza district near the city of Caxias do Sul in the southern Brazilian state of Rio Grande do Sul (RS) at a site $\left(29^{\circ} 07^{\prime} \mathrm{S}, 50^{\circ} 59^{\prime} \mathrm{W}\right)$ belonging to the RS Agroindustrial Research Foundation (Centro de Pesquisas de Agroindústria (CPA) da Fundação Estadual de Pesquisa Agropecuária - FEPAGRO). The site is naturally infested with $R$. solanacearum biovar 2 (race 3 ) and the climate in the area is humid subtropical (Köeppen class $\mathrm{Cfb}$ ) with a mean annual precipitation of $1,633 \mathrm{~mm}$, a mean annual temperature of $15.9^{\circ} \mathrm{C}$ and maximum temperature of 21.8 ${ }^{\circ} \mathrm{C}$.

The experiment was conducted over two potatogrowing seasons, the first experiment being planted on October $18^{\text {th }} 1999$ and the second on October $9^{\text {th }} 2000$, spring in the Southern Hemisphere. The following 14 potato cultivars and clones were planted: Achat, Baraka, Baronesa, Bintje, Catucha, Clone A, Contenda, Cruza 148, Dr McIntosh, Fina, Granola, MB 03, Monalisa, and Rheinhort. For each cultivar or clone we planted 30 tubers, six per plot with five replications, in a completely randomized block design with a row-to-row distance of $0.8 \mathrm{~m}$ and a plantto-plant distance of $0.3 \mathrm{~m}$. The same plots were used in each growing season. The incidence of potato plants with bacterial wilt was recorded each week from 3rd December 1999 until 17th February 2000 for the 1999/2000 season (the 'first season') and from 9th November 2000 until 26th January 2001 for the 2000/2001 season (the 'second season'). We made 12 evaluations in each season and sampled symptomatic potato plants in the 1999/2000 season and in the 2000/2001 season.

\section{Detection of Ralstonia solanacearum in symptomatic plants}

For each cultivar or clone in the plot the area under the disease progress curve (AUDPC) was represented by the sum of the area of the polygons for each evaluation, the AUDPC curve having time (days) as the independent variable and the percentage of symptomatic plants as the dependent variable. The Statistical Analysis Software version 8.1 (Anon., (2000) Statistical Analysis Software (CD-ROM), Version 8.1, SAS Institute Inc., Cary) was used for all the statistical analyses. Initially, the data were tested for normality and the group averages calculated, the average segregation being calculated by applying Tukey-test at the $5 \%$ probability level. The coefficient of determination $\left(\mathrm{R}^{2}\right)$ was obtained from the linear regression of the transformed values for the dependent and independent variables, using the following models: untransformed linear, exponential $(\ln \mathrm{x}), \operatorname{logistic}(\ln \mathrm{x} /(1-\mathrm{x})$, monomolecular $(\ln 1 /(1-\mathrm{x}))$ and 
Epidemiological analysis of clones and cultivars of potato...

Gompertz $(-\ln (-\ln \mathrm{x}))$. The $\mathrm{R}^{2}$ values calculated without transformation were used to determine the best fit for the different models, and were calculated according to Neher et al. (1997) using the SAS program. The standard residue (i.e. the observed minus the expected value) was determined as a function of the independent variable and the estimated standard deviations for the linear coefficient, or intersection, (a) and the angular coefficient, or slope (b). Differences in infection rate between the cultivars and clones were obtained by analysis of variance (ANOVAR) of the angular coefficient (b) of the linear model $(\mathrm{y}=\mathrm{a}+\mathrm{bx})$ curves.

To verify the presence of $R$. solanacearum in wilted potato plants we excised 1 to $2 \mathrm{~cm}$ pieces of stem from symptomatic plants and placed the tissue in micro-centrifuge tubes containing $0.5 \mathrm{~mL}$ of sterilized distilled water and then applied the bacterial flow test. The suspensions were stored at $5{ }^{\circ} \mathrm{C}$ for further isolation of $R$. solanacearum in sucrose peptone agar (SPA, containing $\left(\mathrm{g} \mathrm{L}^{-1}\right)$ : sucrose, 20; peptone, $5 ; \mathrm{K}_{2} \mathrm{HPO}_{4} .7 \mathrm{H}_{2} \mathrm{O}, 0.25$; agar, $15 ; \mathrm{pH} 7.2$ ) containing $0.05 \%$ of tetrazolium triphenyl chloride. Smooth, fluid and elevated colonies with a red center and white periphery, presumptive R. solanacearum (Krieg \& Holt, 1984), were transferred to fresh SPA and incubated at $28{ }^{\circ} \mathrm{C}$ for $48 \mathrm{~h}$, after which material from representative colonies was Gram stained and submitted to the oxidase test, carbohydrate utilization tests for lactose, maltose, trehalose, cellobiose, mannitol, sorbitol and dulcitol being used to determine the biovar (Schaad, 1988). We also carried out DAS-ELISA using $R$. solanacearum polyclonal antiserum (Castro et al., 1993) supplied by Embrapa Temperate Climate (Embrapa Clima Temperado, Pelotas RS) and the cell suspensions made for the bacterial flow test or through maceration of stem segments in extraction buffer (PB $50 \mathrm{mM}$, containing $\left(\mathrm{g} \mathrm{L}^{-1}\right)$ : $\mathrm{Na}_{2} \mathrm{HPO}_{4} 4.26 ; \mathrm{KH}_{2} \mathrm{PO}_{4} 2.72 ; \mathrm{NaN}_{3} 0,1 ; \mathrm{pH}$ 7.2).

\section{Detection of Ralstonia solanacearum in the tubers of asymptomatic plants}

Tubers were sampled from 66 asymptomatic potato plants in the 1999/2000 growing season and from a further 29 asymptomatic plants in the 2000/2001 season, the tubers being collected individually and stored at 25 to $27^{\circ} \mathrm{C}$ until budding.

One tuber per asymptomatic plant was disinfested using $\mathrm{NaOCl} 1 \%(\mathrm{w} / \mathrm{v})$ and sterile distilled water and a core of about $3 \mathrm{~g}$, without the epidermis, was removed from the stolon end and transferred to a plastic bag containing $0.7 \mathrm{~mL}$ of $50 \mathrm{mM}$ phosphate buffer (PB, containing (g. $\left.\mathrm{L}^{-1}\right)$ $\left.\mathrm{Na}_{2} \mathrm{HPO}_{4}, 4.26 ; \mathrm{KH}_{2} \mathrm{PO}_{4}, 2.72 ; \mathrm{NaN}_{3}, 0.1 ; \mathrm{pH} 7.2\right)$ per gram of tuber (Llop et al., 1999) and macerated with a hammer to form a suspension which was filtered through a filter paper and centrifuged at $10,000 \mathrm{~g}$ for $10 \mathrm{~min}$, with the pelleted tissue then re-suspended in the same buffer. Tubers showing no sign of $R$. solanacearum infection were used as a negative control. For $R$. solanacearum detection we used $0.1 \mathrm{~mL}$ of the sample suspension and carried out DAS-ELISA using $R$. solanacearum polyclonal antiserum as described above.
The DNA extraction and amplification were performed as described by Llop et al. (1999). Briefly, the polymerase chain reaction (PCR) was performed in a total volume of $25 \mu \mathrm{L}$ of PCR buffer solution (10 mM Tris-HCl (pH8.3) 50 $\mathrm{mM} \mathrm{KCl}, 3 \mathrm{mM}$ of $\mathrm{MgCl}_{2}$ ), $0.2 \mathrm{mM}$ of each deoxynucleotide (Invitrogen, Brazil), 1.25 units of AmpliTaq polymerase (Gibco-BRL, Brazil), $1 \mu \mathrm{M}$ of the primers OLI1 (5'GGG GGT AGC TTG CTA CCT GCC3') and Y2 (5'CCC ACT GCT GCC TCC CGT AGG AGT3') (Cybersyn, USA) (Seal et al., 1993) and $3 \mu \mathrm{L}$ of diluted sample DNA. Amplification was performed in a Minicycler ${ }^{\mathrm{TM}}$ thermocycler (MJ Research, USA) at $96^{\circ} \mathrm{C}$ for 2 min followed by 35 cycles of $94{ }^{\circ} \mathrm{C}$ for $20 \mathrm{~s}, 68^{\circ} \mathrm{C}$ for $20 \mathrm{~s}$ and $72{ }^{\circ} \mathrm{C}$ for $30 \mathrm{~s}$, with a final $10 \mathrm{~min}$ extension at $72{ }^{\circ} \mathrm{C}$. The products were separated on $1.2 \%$ $(\mathrm{w} / \mathrm{v})$ agarose gel (Gibco-BRL, Brazil) by electrophoresis at $4 \mathrm{~V} \mathrm{~cm}^{-1}$ for $2 \mathrm{~h}$. A $100 \mathrm{bp}$ DNA marker (Gibco-BRL, Brazil) was included in every gel. The gel was dyed with ethidium bromide, visualized under ultra-violet light and photographed using a Kodak Digital Science 1D - EDAS 120 computerized gel analysis system.

\section{RESULTS AND DISCUSSION}

\section{Area under the disease progress curves}

We obtained 84 presumptive $R$. solanacearum isolates from symptomatic plants during the 1999/2000 season and 53 in the 2000/2001 season, all confirmed to be $R$. solanacearum by DAS-ELISA, and biovar 2 (race 3 ) by biochemical tests. The presence of $R$. solanacearum in potato plants from which the bacterium was not isolated was detected by DAS-ELISA.

All cultivars and clones showed plants with symptoms of bacterial wilt in all the replicate plots, except three plots of Cruza 148 cultivar and one plot of MB 03 clone during 1999/2000 season, and two plots of MB 03 clone during 2000/2001 season. Clone MB 03 was selected in Brasília in a field infected with $R$. solanacearum race 1 , and our results suggest that this clone also has a high degree of resistance to $R$. solanacearum biovar 2 (race 3 ).

The exploratory analysis of the AUDPC data showed that it was normally distributed for both seasons, indicating that ANOVAR and the Tukey-test could be applied. For the 1999/2000- season, ANOVAR of the AUDPC data revealed cultivar Cruza 148 and clone MB 03 to be the most resistant to bacterial wilt, while the Baronesa, Catucha and Rheinhort cultivars were the most susceptible. For the 2000/2001 season, the Cruza 148 cultivar and MB 03 clone were again the most resistant plants while the Catucha, Dr. McIntosh and Rheinhort cultivars were the most susceptible (Table 1).

The T-Test was used for a comparative analysis of the homogeneity of the means and variances of the AUDPC data for both seasons and indicated that there was no significant difference $(\mathrm{P}>0.5702)$ between the AUDPC means for the two seasons and that the variances were homogenous $(\operatorname{Pr}>0.3005)$. The inference from these results is that the Cruza 148 cultivar and MB 03 clone (the resistant group) 
TABLE 1 - Area under the disease progress curve (AUDPC) for potato cultivars and clones infested with Ralstonia solanacearum assessed over two growing seasons

\begin{tabular}{|c|c|c|c|c|c|}
\hline \multirow{2}{*}{$\begin{array}{c}\begin{array}{c}\text { Cultivar/ } \\
\text { clone }\end{array} \\
\text { Rheinhort }\end{array}$} & \multicolumn{2}{|c|}{$\begin{array}{l}1999 / 2000^{*} \\
\text { season }\end{array}$} & \multirow{2}{*}{$\begin{array}{l}\text { Cultivar/clone } \\
\text { Reinhort }\end{array}$} & \multicolumn{2}{|c|}{$\begin{array}{c}2000 / 2001^{*} \\
\text { season }\end{array}$} \\
\hline & 4894 & $\mathrm{a}$ & & 5543 & A \\
\hline Baronesa & 4868 & $\mathrm{a}$ & Dr Mc Intosh & 5099 & $\mathrm{Ab}$ \\
\hline Catucha & 4850 & $\mathrm{a}$ & Catucha & 5014 & $\mathrm{Ab}$ \\
\hline Dr McIntosh & 4745 & $a b$ & Bintje & 4775 & $\mathrm{Abc}$ \\
\hline Bintje & 4525 & $a b c$ & Baronesa & 4393 & Abcd \\
\hline Fina & 4286 & $a b c$ & Contenda & 3913 & Abcde \\
\hline Clone A & 3588 & abcd & Clone A & 3399 & Bcde \\
\hline Contenda & 3496 & abcd & Baraka & 3280 & Cdef \\
\hline Monalisa & 2995 & abcd & Fina & 3258 & Cdef \\
\hline Baraka & 2850 & bcd & Monalisa & 2984 & Def \\
\hline Achat & 2680 & $\mathrm{~cd}$ & Achat & 2716 & Def \\
\hline Granola & 2000 & de & Granola & 2281 & Ef \\
\hline MB 03 & 456 & $\mathrm{e}$ & Cruza 148 & 1607 & $\mathrm{Fg}$ \\
\hline Cruza 148 & 307 & $\mathrm{e}$ & MB 03 & 531 & $\mathrm{G}$ \\
\hline
\end{tabular}

"AUDPC means for wilted potato plants growing under natural conditions in fields infested with $R$. solanacearum biovar 2 (race 3 ). Means followed by the same letter are not significantly different by the D.M.S. at the 5\% significance level. The mean significant difference was 1940.8 for the 1999 to 2000 growing season and 1711.5 for the 2000 to 2001 growing season.

were the most resistant to bacterial wilt, while the Catucha and Rheinhort cultivars (the susceptible group) were the most susceptible, with the remaining cultivars and clones comprising a stratified intermediate group with clone A at the center and the Granola, Achat, Monalisa and Baraka cultivars close to the resistant group and the Dr McIntosh, Bintje, Baronesa, Fina and Contenda cultivars close to the susceptible group.

The Baronesa and Catucha cultivars were produced in the Southern Region breeding programs, and were selected in fields subjected to infestation with $R$. solanacearum, supposedly race 3 . Our evaluation of these cultivars confirms the report by Lopes et al. (1993) that potato cultivars and clones selected in Southern Region are significantly more susceptible to wilt compared to the standard Achat cultivar, although this cultivar was obtained without selective pressure. At present, 'Achat' is the only cultivar with partial horizontal resistance available in Brazil, although because of its low culinary quality, this cultivar has been almost completely supplanted in Brazil by other cultivars. Another factor is that 'Achat' does not flower in Brazil, which makes its use impossible in regular breeding programs. This cultivar was produced from a cross between the Fina and Rheinhort cultivars (Hamester \& Hills, 1999), and it is interesting to note that in our study both these cultivars were more susceptible than 'Achat' and that in both seasons 'Rheinhort' was the most susceptible of all the cultivars evaluated. Under conditions of Central Brazil Region, Quezado-Soares et al. (1997) assessed some potato cultivars in an area naturally infested with $R$. solanacearum biovar 1 and reported that
'Rheinhort' was susceptible to wilt.

Rieseberg et al. (2003) have pointed out that the resistance of a progeny obtained from susceptible genitors is due to a beneficial combination of partial resistance genes (transgressive segregation). Tung et al. (1990a, b) and Tung (1992) suggest assessing not only resistance genes but also those involved in adaptation to a particular environment and have also pointed out that the resistance of potato plants to $R$. solanacearum is governed by "minor effect" genes and that a suitable combination of resistance and environmental adaptation genes is needed for the effective expression of resistance to bacterial wilt. The possible resistance of the Dr. McIntosh cultivar, which has a clone of Solanum phureja as one of its genitors, was not confirmed by us.

\section{Fitting the disease progress curves to the epidemiological models}

For all the genotypes in both seasons the logistic model best fitted the bacterial wilt progress curves. The untransformed observed and expected coefficient of determination values $\left(\mathrm{R}^{2}\right)$, linear coefficient, or intersection, (a) and angle coefficient, or slope, (b) are listed by genotype in Table 2.

Neher \& Campbell (1997) state that for the best fit the $\mathrm{R}^{2}$ value for a model should exceed $80 \%$. In our case, the $\mathrm{R}^{2}$ value was greater than $80 \%$ for the logistic model

TABLE 2 - Linear regression analysis for the logistic model for bacterial wilt progress in potato cultivars and clones planted in two growing seasons (1999/2000 and 2000/2001) in areas naturally infested with Ralstonia solanacearum

\begin{tabular}{|c|c|c|c|c|c|c|}
\hline \multirow[b]{2}{*}{ Cultivar } & \multicolumn{3}{|c|}{$1999 / 2000$ season } & \multicolumn{3}{|c|}{ 2000/2001 season } \\
\hline & $\mathbf{R}^{2}(\%)$ & $\mathbf{a}$ & $\mathbf{b}$ & $\mathbf{R}^{2}(\%)$ & $\mathbf{a}$ & B \\
\hline Achat & 61.0 & 0.14 & 0.76 & 78.8 & 0.08 & 0.89 \\
\hline Baraka & 78.4 & 0.04 & 0.86 & 72.8 & 0.05 & 0.91 \\
\hline Baronesa & 78.6 & 0.12 & 0.85 & 78.0 & 0.09 & 0.86 \\
\hline Bintje & 68.5 & 0.10 & 0.81 & 94.5 & 0.01 & 0.98 \\
\hline Catucha & 78.2 & 0.02 & 0.95 & 81.5 & 0.05 & 0.92 \\
\hline Clone A & 70.5 & 0.13 & 0.83 & 77.5 & 0.06 & 0.88 \\
\hline Contenda & 81.6 & 0.02 & 0.95 & 81.5 & 0.04 & 0.90 \\
\hline Cruza 148 & 9.9 & 0.03 & 0.02 & 57.0 & 0.09 & 0.64 \\
\hline Dr Mc Intosh & 76.8 & 0.05 & 0.92 & 89.8 & 0.02 & 0.96 \\
\hline Fina & 76.7 & 0.06 & 0.88 & 83.1 & 0.04 & 0.95 \\
\hline Granola & 60.1 & 0.08 & 0.75 & 71.0 & 0.08 & 0.87 \\
\hline MB 03 & 14.7 & 0.07 & 0.14 & 15.5 & 0.09 & 0.07 \\
\hline Monalisa & 80.8 & 0.07 & 0.90 & 74.4 & 0.07 & 0.86 \\
\hline Rheinhort & 52.7 & 0.21 & 0.67 & 69.49 & 0.10 & 0.81 \\
\hline
\end{tabular}

Key: $\mathrm{R}^{2}=$ coefficient of determination for fitness between the untransformed observed and expected values; $\mathrm{a}=$ linear coefficient (intersection) and $\mathrm{b}=$ angle coefficient (slope) of the fitness equation for the linearized logistic model $\mathrm{Y}=\mathrm{a}+\mathrm{bX}$. 
Epidemiological analysis of clones and cultivars of potato...

for the Contenda and Monalisa cultivars in the 1999/2000 season and for the Bintje, Dr McIntosh, Fina, Contenda and Catucha cultivars in the 2000/2001 season. Except for the Baraka, Monalisa, Baronesa and Contenda cultivars, the disease progress curves in the 2000/2001 season better fitted the logistic model than was the case in the 1999/2000 season. All the models (linear, exponential, monomolecular, logistic and Gompertz) showed an $\mathrm{R}^{2}$ value of less than $50 \%$ for the Cruza 148 cultivar in the 1999/2000 season and for the MB 03 clone in both seasons, indicating that the most resistant genotypes did not present the same epidemiological pattern as the susceptible genotypes.

The slope angle (b) is related to the rate of disease in the field, and this rate was compared by ANOVAR of the angles. The data from 'Cruza 148' and the MB 03 clone showed no proper fit and no significant difference was found by the Tukey test (5\%) for the 1999/2000 season, although for the 2000/2001 season 'Bintje' presented a significantly higher slope angle (Tukey-test, $\mathrm{P}=95 \%$ ) than that for the other cultivars.

A mean analysis of the slope coefficients (b) was performed for both seasons using T-Test but showed no homogeneity $(\operatorname{Pr}>0.0164)$, which meant that a comparative analysis of the data regarding the 1999/2000 and 2000/2001 seasons could not be made.

As only the Bintje cultivar had a different slope coefficient from the other cultivars during the 2000/2001 season the significant differences observed by AUDPC could have been related to the post-planting time on which the initial wilt symptoms appeared. To investigate this possibility we calculated the correlation coefficient between the AUDPC and the number of days after planting on which symptoms of wilt first appeared. The correlation between the variables was highly significant $(\operatorname{Pr}>0.0001)$ for both seasons, with the regression coefficient ( $\mathrm{r}$ ) being -0.9227 for the $1999 / 2000$ season and -0.8794 for the $2000 / 2001$ season (Figure 1). Based on these results, it can be inferred that the beginning of the epidemic depends on the resistance of the cultivar and that the AUDPC is related to the number of days after planting on which symptoms of wilt first appear.

A comparative analysis of the data for both planting seasons showed that the variances were homogenous $(\operatorname{Pr}>$ 0.7195 ) and that the difference between the mean number of days after planting on which symptoms of wilt first appeared was highly significant $(\operatorname{Pr}>0.0001)$ by the T-Test.

In the 1999/2000 season symptoms of wilt began at least 15 days later than in the 2000/2001 season, which may have been due to the lower precipitation $(479.4 \mathrm{~mm})$ during August to December 1999 than August to December 2000 $(870.6 \mathrm{~mm})$ as recorded at the city of Caxias do Sul (CPA/ FEPAGRO). The monthly average precipitation for August to December over the 30 years from 1945 to 1974 was 771 mm (Maluf et al., 1989).

For the majority of cultivars, in both seasons, it was not possible to obtain a fit higher than $80 \%$ in respect to the linearized models for $\mathrm{R}^{2}$, so we attempted to fit the data to

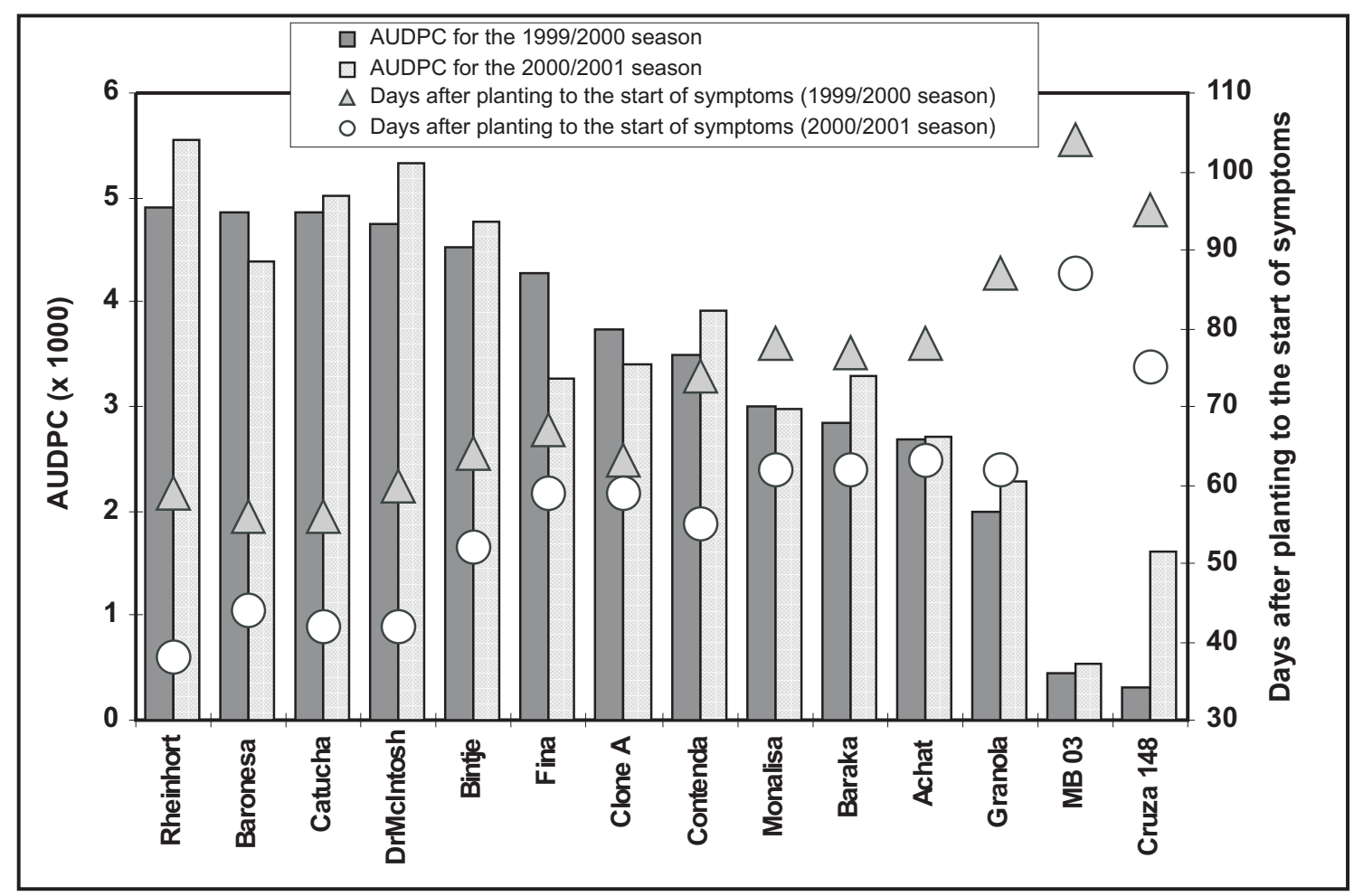

FIG. 1 - Area under the disease progress curve (AUDPC) and the number of days after planting before the start of wilt symptoms in potato cultivars and clones planted in an area naturally infested with Ralstonia solanacearum. 
the non-linearized logistic, monomolecular, and Gompertz models, as suggested by Neher \& Campbell (1997). The $\mathrm{R}^{2}$ determination coefficient, the standard error of the asymptote for the parameters of the wilt incidence rate $(R)$ and the level of wilt at the first observation ( $\mathrm{Y}_{\mathrm{o}}$ ), as well as the plotted data, were the criteria used for assessing the fit of the models. The asymptotic standard errors for the $\mathrm{R}$ and $\mathrm{Y}_{\mathrm{o}}$ parameters fit more closely the closer they get to zero. Based on these criteria, the best model for the cultivars seems to be the logistic model because the $\mathrm{R}^{2}$ value for the logistic model resulted in a higher number of cultivars, with $\mathrm{R}^{2}$ values exceeding $80 \%$ for the $1999 / 2000$ season, and did not change the number of cultivars for the 2000/2001 season.

The results of the fitness tests for the nonlinearized logistic model and for the coefficient of determination $\left(\mathrm{R}^{2}\right)$ are shown in Table 3. In the $1999 / 2001$ season the $\mathrm{R}^{2}$ value for the non-linearized model was not satisfactory for 'Cruza 148' and clone MB 03, the most wilt-resistant genotypes, possibly due to the duration of infection for these genotypes, which was 35 days for 'Cruza 148' and 28 days for clone MB 03 and corresponded to four or five observation dates. For the 2000/2001 season, the symptoms of the MB 03 clone were recorded only on the last four observation dates. According to Neher \& Campbell (1997) the fitness model can fail because the number of observations (dates of observation or data collection) are insufficient to support the principle characteristics of the model.

\section{Detection of Ralstonia solanacearum in tubers of asymptomatic plants}

The tubers sampled from asymptomatic plants and stored at $25-27^{\circ} \mathrm{C}$ until budding presented no vascular discoloration when cut transversely. However, some tubers were positive for $R$. solanacearum by DAS-ELISA and PCR, indicating the latent nature of the infection in resistant genotypes as well as in susceptible ones (Table 4).

When submitted to DAS-ELISA, 37 out of 66 tubers (56\%) from the 1999/2000 season and 11 out of 29 tubers (38\%) from the 2000/2001 season were positive for $R$. solanacearum. The percentage of PCR samples positive for $R$. solanacearum was $74 \%$ for the $1999 / 2000$ season and $55 \%$ for the $2000 / 2001$ season, indicating the higher sensitivity of this test.

Using the same DNA extraction method and primers (Oli 1 and Y2) as were used by us, Llop et al. (1999) found that PCR was more efficient at detecting latent infections of potato tubers as compared to ELISA and immunofluorescence tests using polyclonal anti-sera or traditional microbiological methods, with PCR being able to detect as few as 100 colony forming units (CFU). $\mathrm{mL}^{-1}$.

Several sensitive and rapid methods have been developed for detecting $R$. solanacearum and monitoring its occurrence in potato tubers to satisfy phytosanitary regulations

TABLE 3 - Regression analysis for the non-linearized logistic model for bacterial wilt progress in potato cultivars and clones planted in two growing seasons (1999/2000 and 2000/2001) in areas naturally infested with Ralstonia solanacearum

\begin{tabular}{|c|c|c|c|c|c|c|c|c|}
\hline \multirow[b]{2}{*}{ Cultivar } & \multicolumn{4}{|c|}{$1999 / 2000$ season } & \multicolumn{4}{|c|}{$2000 / 2001$ season } \\
\hline & $\mathbf{R}^{2}(\%)$ & Yo $\left(\mathrm{x} 10^{-6}\right)$ & $\mathbf{R}_{\mathbf{L}}$ & B & $\mathbf{R}^{2}(\%)$ & Yo $\left(\mathrm{x} 10^{-6}\right)$ & $\mathbf{R}_{\mathbf{L}}$ & B \\
\hline Achat & 60.8 & 364 & 0.08 & 7.92 & 79.4 & 84 & 0.12 & 9.38 \\
\hline Baraka & 78.0 & 67 & 0.10 & 9.61 & 75.5 & 563 & 0.10 & 7.48 \\
\hline Baronesa & 79.5 & 2890 & 0.08 & 5.84 & 78.3 & 1800 & 0.10 & 6.32 \\
\hline Bintje & 72.2 & 969 & 0.09 & 6.94 & 94.3 & 0.15 & 0.26 & 15.67 \\
\hline Catucha & 84.2 & 2330 & 0.08 & 6.06 & 82.7 & 266 & 0.14 & 8.23 \\
\hline Clone A & 71.0 & 1940 & 0.07 & 6.24 & 78.1 & 573 & 0.10 & 7.46 \\
\hline Contenda & 81.8 & 105 & 0.10 & 9.16 & 82.5 & 289 & 0.12 & 8.15 \\
\hline Cruza 148 & 9.7 & 184 & 0.06 & 8.60 & 55.7 & 178 & 0.09 & 8.63 \\
\hline Dr McIntosh & 82.6 & 778 & 0.09 & 7.16 & 90.3 & 40 & 0.18 & 10.13 \\
\hline Fina & 82.0 & 116 & 0.11 & 9.06 & 84.4 & 209 & 0.11 & 8.47 \\
\hline Granola & 61.7 & 159 & 0.08 & 8.75 & 73.3 & 586 & 0.08 & 7.44 \\
\hline MB 03 & 16.1 & 227 & 0.06 & 8.39 & 15.2 & 361 & 0.07 & 7.93 \\
\hline Monalisa & 84.7 & 6.38 & 0.13 & 11.96 & 75.0 & 429 & 0.10 & 7.75 \\
\hline Rheinhort & 57.4 & 6880 & 0.69 & 4.97 & 69.7 & 4990 & 0.10 & 5.29 \\
\hline
\end{tabular}

Key: $\mathrm{R}^{2}=$ coefficient of determination for the logistic model; Yo = level of the disease at the first observation, $\mathrm{R}_{\mathrm{L}}=$ disease incidence rate for the logistic model; $\mathrm{B}=$ function of the disease proportion at the first observation for the logistic model (- $\mathrm{Ln}(\mathrm{Yo} /(\mathrm{K}-\mathrm{Yo}))$ for the non-linear arrangement equation with $\mathrm{K}_{\max }$ $=1.0, \mathrm{Y}=1 /\left(1+\exp \left(\mathrm{B}-\mathrm{R}_{\mathrm{L}} \mathrm{t}\right)\right)$ and $\mathrm{t}=$ duration of the epidemic. 
TABLE 4 - Number of potato plants positive for Ralstonia solanacearum but from potato cultivars and clones asymptomatic for bacterial wilt when planted in two growing seasons (1999/2000 and 2000/2001) in an area naturally infested with Ralstonia solanacearum. The tests carried out were the double antibody sandwich enzyme-linked immunosorbent assay (DAS-ELISA) using Polyclonal anti-serum related to $R$. solanacearum (Castro et al.. 1993) and the polymerase chain reaction (PCR) using the Oli 1 and Y2 primers (Seal et al.. 1993). One tuber per asymptomatic plant was tested with two replicates

\begin{tabular}{|c|c|c|c|c|}
\hline \multirow[t]{2}{*}{ Season } & \multirow{2}{*}{$\begin{array}{l}\text { Cultivars and clones with } \\
\text { some asymptomatic plants }\end{array}$} & \multirow{2}{*}{$\begin{array}{c}\text { Number of } \\
\text { asymptomatic plants }\end{array}$} & \multicolumn{2}{|c|}{$\begin{array}{c}\text { Number of asymptomatic } \\
\text { plants positive by: }\end{array}$} \\
\hline & & & DAS-ELISA & PCR \\
\hline \multirow[t]{8}{*}{$1999 / 2000$} & Achat & 3 & 2 & 2 \\
\hline & Baraka & 4 & 4 & 4 \\
\hline & Baronesa & 1 & 0 & 1 \\
\hline & Clone A & 1 & 0 & 1 \\
\hline & Contenda & 3 & 0 & 2 \\
\hline & Cruza 148 & 25 & 15 & 20 \\
\hline & Granola & 7 & 7 & 7 \\
\hline & MB 03 & 22 & 9 & 12 \\
\hline \multirow[t]{4}{*}{$2000 / 2001$} & Cruza 148 & 7 & 5 & 6 \\
\hline & Granola & 1 & 0 & 0 \\
\hline & MB 03 & 20 & 6 & 9 \\
\hline & Monalisa & 1 & 0 & 1 \\
\hline
\end{tabular}

aimed at minimizing dissemination of the pathogen through infected tubers (Elphinstone et al., 1996; Priou et al., 1999; Llop et al., 1999; Martins, 2000). Seal et al. (1993) reported that PCR can detect as few as one to ten $R$. solanacearum cells, although this level of sensitivity could not be reproduced by other workers (Elphinstone et al., 1996; Martins, 2000). New methods have produced an increase in the sensitivity of detection techniques, an example being the use of a pretreatment protocol involving semi-selective enrichment medium plus the addition of $0.05 \mathrm{M} \mathrm{NaOH}$ and heating at $100{ }^{\circ} \mathrm{C}$ for 6 minutes during the PCR (Elphinstone et al., 1996). Martins (2000) determined the sensitivity of the PCR technique for potato tuber samples as

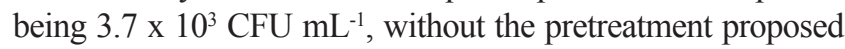
by Elphinstone et al. (1996), and concluded that traditional microbiological methods are more sensitive and, therefore, recommended them as a standard procedure for the detection of $R$. solanacearum. Martins (2000) also recognized that PCR can be important for the detection of pathogens that cannot be grown using selective medium. However, the European and Mediterranean Organization for the protection of plants recommends the use of PCR, bacterial growth using semiselective medium, immunofluorescence test and biological tests in tomato and eggplant seedlings (OEPP/EPPO, 1998, 1999).

Our results indicate that PCR is the most sensitive method to detect $R$. solanacearum in tubers but that it still depends on bacterial isolation, which is time-consuming. Therefore, in future work we intend to improve the method of DNA extraction from tuber tissue without bacterial isolation on culture medium.

\section{REFERENCES}

CASTRO, L.A.S., DANIELS, J. \& COUTO, M.E.O. Utilização do teste de ELISA na diagnose de Pseudomonas solanacearum. Fitopatologia Brasileira 18:296. 1993. (Resumo)

ELPHINSTONE, J.G., HENNESSY, J., WILSON, J.K. \& STEAD, D.E. Sensitivity of different methods for the detection of Ralstonia solanacearum in potato tuber extracts. OEPP/EPPO Bulletin 26:663-678. 1996

FRENCH, E.R., ANGUIZ, R. \& ALEY, P. The usefulness of potato resistance to Ralstonia solanacearum, for the integrated control of bacterial wilt. 1997. Reports, $2^{\circ}$ International Bacterial Wilt Symposium, Guadeloupe. 1998. pp.381-385.

HAMESTER, W. \& HILLS, V. World catalogue of potato varieties. Berlin. Bergen Agrimedia. 1999.

HAYWARD, A.C. Pseudomonas solanacearum. In: Singh, U., Singh, R. \& Kohmoto, K. (Eds.) Pathogenesis and host specificity in plant diseases: Histopathological, biochemical, genetic and molecular bases. Oxford. Pergamon. 1995. pp. 139-151.

HAYWARD, A.C. Biology and epidemiology of bacterial wilt caused by Pseudomonas solanacearum. Annual Review of Phytopathology 29:65-87. 1991.

LLOP, P., CARUSO, P., CUBERO, J., MORENTE, C. \& LÓPEZ, M.M. A simple extraction procedure for efficient routine detection of pathogenic bacteria in plant material by polymerase chain reaction. Journal of Microbiological Methods 37:23-31. 1999.

LOPES, C.A. Ecologia de Pseudomonas solanacearum. 1993. Brasília, DF. Memórias, Taller Sobre Enfermedades Bacterianas de La Papa, 1994. pp. 17-22. 
LOPES, C.A., LIMA, B.J.C. \& BUSO, J.A. Reaction of Brazilian potato varieties to bacterial wilt, 1990. Biological and Cultural Tests 8:38. 1993.

LOPES, C.A., QUEZADO-SOARES, A.M., BUSO, J.A. \& MELO, P.E. Breeding for resistance to bacterial wilt of potatoes in Brazil.1997. Reports, $2^{\circ}$ International Bacterial Wilt Symposium, Guadeloupe. 1998. pp. 291-293.

MALUF, J.R.T., DIDONÉ, I. \& BERLATO, M.A. Atlas agroclimático. Porto Alegre RS. Secretaria da Agricultura e Abastecimento do Estado do Rio Grande do Sul. 1989.

MARTINS, O.M. Polymerase chain reaction in the diagnosis of bacterial wilt, caused by Ralstonia solanacearum (Smith) Yabuuchi et al. PhD Thesis. Georg-August Universität Göttingen. 2000.

NEHER, D.A. \& CAMPBELL, C.L. Analysis of disease progress curves using nonlinear models. In: Francl, L.J. \& Neher, D.A. (Eds.) Exercises in plant disease epidemiology. Saint Paul MN. APS Press. 1997. pp. 38-40.

NEHER, D.A., REYNOLDS, K.L. \& CAMPBELL, C.L. Analysis of disease progress curves using linear models. In: Francl, L.J. \& Neher, D.A. (Eds.) Exercises in plant disease epidemiology. Saint Paul MN. APS Press. 1997. pp. 29-33.

OEPP/EPPO. Surveys carried out in Germany on Ralstonia solanacearum. EPPO Reporting Service. 98/147. 1998.

OEPP/EPPO. Surveys on Clavibacter michiganense subspecies sepedonicus and Ralstonia solanacearum in Germany. EPPO Reporting Service. 99/054. 1999.

PRIOU, S., GUTARRA, L., FERNANDEZ, H. \& ALEY, P. Sensitive detection of Ralstonia solanacearum in latently infected potato tubers and soil by post-enrichment ELISA. In: CIP (Ed.) Impact in a changing world. Lima. International Potato Center. 1999. pp. 111-121.

QUEZADO-SOARES, A.M., LOPES, C.A., BUSO, J.A. \& MELO, P. Evaluation in Brazil of potato clones resistant to bacterial wilt in the Philippines. Bacterial Wilt Newsletter 14:1-3. 1997.
REIFSCHNEIDER, F.J.B. \& LOPES, C.A. Resistência de plantas a fitobactérias. Fitopatologia Brasileira 22(Supl.):41-46. 1997.

RIESEBERG, L.H., WIDMER, A., ARNTZ, A.M. \& BURKE, J.M. The genetic architecture necessary for transgressive segregation is common in both natural and domesticated populations. Philosophical Transactions of the Royal Society of London. Series B, Biological Sciences 358:1141-1147. 2003.

SCHAAD, N.W. Laboratory Guide for Identification of Plant Pathogenic Bacteria. 2nd ${ }^{\text {nd }}$ ed Saint Paul MN. APS Press. 1988.

SEAL, E.S., JACKSON, L.A. \& DANIELS, M.J. Differentiation of Pseudomonas solanacearum, Pseudomonas syzygii, Pseudomonas pickettii and the blood disease bacterium by partial $16 \mathrm{~S}$ rRNA sequencing: construction of oligonucleotide primers for sensitive detection by polymerase chain reaction. Journal of General Microbiology 139:1587-1594. 1993.

SILVEIRA, J.R.P., DUARTE, V. \& MORAES, M.G. Ocorrência das biovares 1 e 2 de Ralstonia solanacearum em lavouras de batata no Estado do Rio Grande do Sul. Fitopatologia Brasileira 27:450-453. 2002.

TUNG, P.X., RASCO, E.T., ZAAG, P.V. \& SCHMIEDICHE, P. Resistance to Pseudomonas solanacearum in the potato: I Effects of sources of resistance and adaptation. Euphytica 45:203-210. 1990a.

TUNG, P.X., RASCO, E.T., ZAAG, P.V. \& SCHMIEDICHE, P. Resistance to Pseudomonas solanacearum in the potato: II Aspects of host-pathogen-environment interaction. Euphytica 45:211-215. 1990b.

TUNG, P.X. Genetic variation for bacterial wilt resistance in a population of tetraploid potato. Euphytica 61:73-80. 1992.

YABUUCHI, E., KOSAKO, Y., YANO, I., HOTTA, H. \& NISHIUCHI, Y. Transfer of two Burkholderia and an alcaligenes species to Ralstonia gen. nov.: Proposal of Ralstonia picketti (Ralston, Palleroni and Duodoroff 1973) comb. nov., Ralstonia solanacearum (Smith 1896) comb. nov. and Ralstonia eutropha (Davis 1969) comb. nov. Microbiology and Immunology 39:897-904. 1995. 